\title{
Impact on child mortality of removing user fees: simulation model
}

\author{
Chris James, Saul S Morris, Regina Keith, Anna Taylor
}

\begin{abstract}
Objective To estimate how many child deaths might be prevented if user fees were removed in 20 African countries

Design Simulation model combining evidence on key health interventions' impacts on reducing child mortality with analysis of the effect of fee abolition on access to healthcare services.

Results Elimination of user fees could prevent approximately 233000 (estimate range 153 000-305 000) deaths annually in children aged under 5 in 20 African countries.

Conclusion Given the relatively low cost of abolition, replacing user fees with alternative financing mechanisms should be seen as an effective first step towards improving households' access to health care and achieving the millennium development goals for health.
\end{abstract}

\section{Introduction}

User fees-charges for health care at the point of useare in place in most sub-Saharan African countries. Their introduction was justified as a pragmatic solution to severe under-funding, as well as part of a broader ideological shift in health policy that emphasised efficiency. However, evidence from a broad range of African contexts indicates that fees have rarely generated large amounts of revenue, are unlikely to have improved (and might even have worsened) allocative efficiency, and have too often disproportionately affected poor people. ${ }^{1}$ Perhaps more striking than this evidence on implementation of user fees is the potential magnitude of gains from their abolition in terms of lives saved. We aimed to model how many child deaths might be prevented if user fees were removed in 20 African countries.

\section{Methods}

We estimated the number of deaths in children aged under 5 years that could be prevented through abolition of user fees by combining evidence on the impact that key health interventions have in reducing child mortality ${ }^{2}{ }^{3}$ with analysis of the potential of such abolition to increase the proportion of the population benefiting from these interventions. This analysis can only give a first estimate of the likely impact of abolition of fees, as the context of individual countries will determine the exact nature of the changes seen.

Our approach can be summarised as follows (see appendix on bmj.com for full details). In a first stage, we developed a classification system for key interventions to improve child survival. This classified 26 interventions according to whether their use is expected to increase after abolition of fees and if so by how much (figure ). We based this grouping primarily on the expected magnitude of price reduction after fee abolition, but it also incorporates effects on health promotion. The classification is based on representative prices across the region, rather than exact figures from any one country. However, in some countries (or regions within countries) a flat rate fee may be charged, at least in principle. We therefore also did a sensitivity analysis to reflect this situation. Importantly, the model assumes improvements in access after removal of fees, even if countries have waiver or exemption mechanisms for children under 5 and pregnant women (as is the case, for example, in Tanzania), as widespread evidence shows that these have generally been ineffective. ${ }^{45}$

An appendix describing methods is on bmj.com

Save the Children

UK, London

EC1M 4AR

Chris James

health financing

consultant

Regina Keith

health policy adviser

Anna Taylor

head of basic services

London School of

Hygiene and

Tropical Medicine,

London

WC1E 7HT

Saul S Morris

honorary senior

lecturer

continued over

BMJ 2005;331:747-9

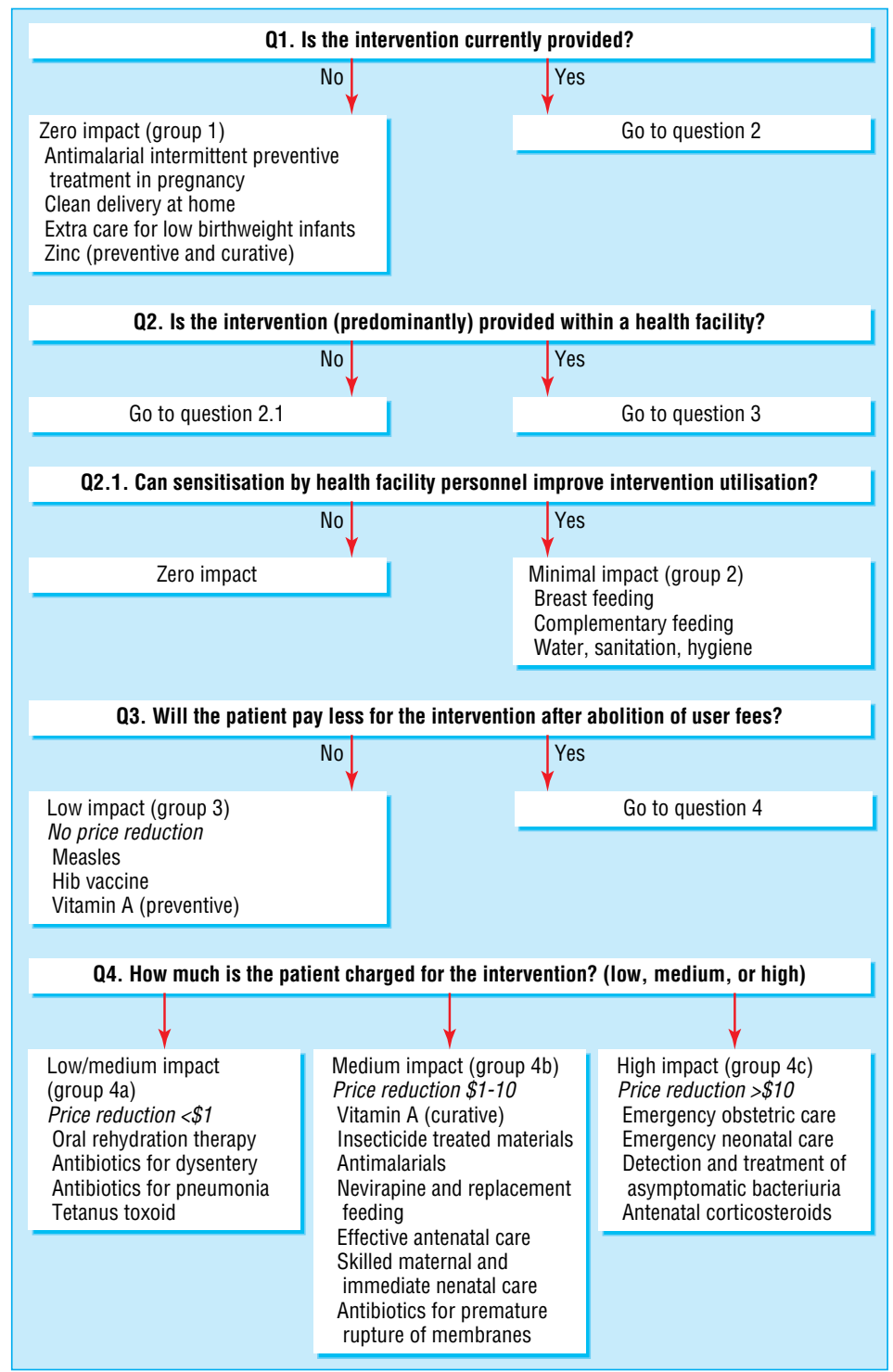

Expected positive effects of abolition of user fees on access to key child health interventions 
Correspondence to: C James, Rustlings, Springwood Lane, Peppard,

Henley-on-Thames,

Oxon RG9 5JJ

chrisjamesuk@

hotmail.com
In the second stage of model development, we combined this intervention classification system with evidence from Uganda, South Africa, Madagascar, and Kenya on more generalised changes in use of health services after fee abolition, ${ }^{3}{ }^{3-10}$ to produce estimates of expected changes in utilisation rate for each of the 26 interventions (table). We did this by adjusting the generalised utilisation changes from these four countries downwards or upwards, according to each intervention's classification. We explored two basic scenarios: the Ugandan experience (analysed separately because of its more detailed data) and other post-fee abolition studies. For both, we also estimated expected higher increases in utilisation by poor people-poor (and near poor) people have typically been the most responsive to price changes and have higher rates of illness ${ }^{11-13}$ giving four scenarios in total.

In a third stage, we converted these estimated increases in use of different health interventions into plausible reductions in mortality in children under 5 . We did this by inputting estimates of expected proportional increases in the coverage of each intervention from 2003 levels into the updated Bellagio child survival impact model. This model estimates effects on child

Estimated changes in utilisation rate (UR $\Delta$ ) after abolition of user fees, based on experience in four countries. Values are percentages

Scenario 1: Uganda experience

URA observations: intervention proxies

\begin{tabular}{|c|c|c|c|c|c|c|c|c|c|c|c|c|}
\hline \multirow[b]{4}{*}{$\begin{array}{l}\text { Child survival } \\
\text { interventions }\end{array}$} & \multicolumn{7}{|c|}{ Scenario 1: Uganda experience } & \multicolumn{5}{|c|}{ Scenario 2: Other post-fee abolition studies } \\
\hline & \multicolumn{6}{|c|}{ URA observations: intervention proxies } & \multirow{3}{*}{$\begin{array}{c}\text { URA } \\
\text { estimates§: } \\
\text { intervention } \\
\text { specific }\end{array}$} & \multicolumn{4}{|c|}{ URA observations: intervention proxies } & \multirow{3}{*}{$\begin{array}{c}\text { URA } \\
\text { estimates§: } \\
\text { intervention } \\
\text { specific }\end{array}$} \\
\hline & \multicolumn{2}{|c|}{ Burnham et $a^{6 *}$} & \multicolumn{2}{|c|}{ Deininger and $\mathrm{Mpuga}^{7} \dagger$} & \multicolumn{2}{|c|}{ Nabyonga et $a^{5} \ddagger$} & & \multicolumn{2}{|c|}{$\begin{array}{l}\text { Wilkinson et a } 1^{10} \\
\text { (South Africa)ףा }\end{array}$} & \multicolumn{2}{|c|}{$\begin{array}{c}\text { Fafchamps and Minten }^{9} \\
\text { (Madagascar), Mwabu et al }^{9} \\
\text { (Kenya)** }\end{array}$} & \\
\hline & $\begin{array}{l}\text { Intervention } \\
\text { proxy }\end{array}$ & URA & $\begin{array}{l}\text { Intervention } \\
\text { proxy }\end{array}$ & URA & $\begin{array}{l}\text { Intervention } \\
\text { proxy }\end{array}$ & URA & & $\begin{array}{l}\text { Intervention } \\
\text { proxy }\end{array}$ & URA & $\begin{array}{l}\text { Intervention } \\
\text { proxy }\end{array}$ & URA & \\
\hline Group 1 interventions & $\begin{array}{l}\text { No intervention } \\
\text { currently provid }\end{array}$ & $\begin{array}{l}\text { proxies } \\
\text { ed }\end{array}$ & zero impact, as & & & & 0 & & & & & 0 \\
\hline Group 2 interventions & $\begin{array}{l}\text { No intervention } \\
\text { evidence }\end{array}$ & proxies & zero impact, as & & & & 0 & & & & & 0 \\
\hline \multicolumn{13}{|l|}{ Group 3 interventions: } \\
\hline Vitamin A (preventive) & $\begin{array}{l}\text { Average } \\
\text { (preventive) }\end{array}$ & 24.9 & $\begin{array}{l}\text { Vitamin A } \\
\text { supplementatio }\end{array}$ & 61.0 & Preventive & 0 & 12.5 & Preventive & 0 & General, all ages & 21 and 41 & 10.5 \\
\hline Measles vaccine & Immunisations & 17.2 & $\begin{array}{l}\text { Average } \\
\text { (preventive) }\end{array}$ & 36.3 & Preventive & 0 & 8.6 & Preventive & 0 & General, all ages & 21 and 41 & 10.5 \\
\hline Hib vaccine & Immunisations & 17.2 & $\begin{array}{l}\text { Average } \\
\text { (preventive) }\end{array}$ & 36.3 & Preventive & 0 & 8.6 & Preventive & 0 & General, all ages & 21 and 41 & 10.5 \\
\hline \multicolumn{13}{|l|}{ Group 4a interventions: } \\
\hline Oral rehydration therapy & $\begin{array}{l}\text { Curative, } \\
\text { under } 5\end{array}$ & 27.3 & $\begin{array}{l}\text { Curative, } \\
\text { under } 5\end{array}$ & 18.5 & $\begin{array}{l}\text { Curative, } \\
\text { under } 5\end{array}$ & 40 & 20.5 & $\begin{array}{l}\text { Curative, } \\
\text { all ages }\end{array}$ & 77 & General, all ages & 21 and 41 & 30.8 \\
\hline Antibiotics for dysentery & $\begin{array}{l}\text { Curative, } \\
\text { under } 5\end{array}$ & 27.3 & $\begin{array}{l}\text { Curative, } \\
\text { under } 5\end{array}$ & 18.5 & $\begin{array}{l}\text { Curative, } \\
\text { under } 5\end{array}$ & 40 & 20.5 & $\begin{array}{l}\text { Curative, } \\
\text { all ages }\end{array}$ & 77 & General, all ages & 21 and 41 & 30.8 \\
\hline $\begin{array}{l}\text { Antibiotics for } \\
\text { pneumonia }\end{array}$ & $\begin{array}{l}\text { Curative, } \\
\text { under } 5\end{array}$ & 27.3 & $\begin{array}{l}\text { Curative, } \\
\text { under } 5\end{array}$ & 18.5 & $\begin{array}{l}\text { Curative, } \\
\text { under } 5\end{array}$ & 40 & 20.5 & $\begin{array}{l}\text { Curative, } \\
\text { all ages }\end{array}$ & 77 & General, all ages & 21 and 41 & 30.8 \\
\hline Tetanus toxoid & Immunisations & 17.2 & $\begin{array}{l}\text { Average } \\
\text { (preventive) }\end{array}$ & 36.3 & Preventive & 0 & 12.9 & Preventive & 0 & General, all ages & 21 and 41 & 15.8 \\
\hline \multicolumn{13}{|l|}{ Group 4b interventions: } \\
\hline Vitamin A (curative) & $\begin{array}{l}\text { Curative, } \\
\text { under } 5\end{array}$ & 27.3 & $\begin{array}{l}\text { Curative, } \\
\text { under } 5\end{array}$ & 18.5 & $\begin{array}{l}\text { Curative, } \\
\text { under } 5\end{array}$ & 40 & 27.3 & $\begin{array}{l}\text { Curative, } \\
\text { all ages }\end{array}$ & 77 & General, all ages & 21 and 41 & 41.0 \\
\hline $\begin{array}{l}\text { Insecticide treated } \\
\text { materials }\end{array}$ & $\begin{array}{l}\text { Average } \\
\text { (preventive) }\end{array}$ & 24.9 & $\begin{array}{l}\text { Average } \\
\text { (preventive) }\end{array}$ & 36.3 & Preventive & 0 & 24.9 & Preventive & 0 & General, all ages & 21 and 41 & 21.0 \\
\hline Antimalarials & $\begin{array}{l}\text { Curative, } \\
\text { under } 5\end{array}$ & 27.3 & $\begin{array}{l}\text { Curative, } \\
\text { under } 5\end{array}$ & 18.5 & $\begin{array}{l}\text { Curative, } \\
\text { under } 5\end{array}$ & 40 & 27.3 & $\begin{array}{l}\text { Curative, } \\
\text { all ages }\end{array}$ & 77 & General, all ages & 21 and 41 & 41.0 \\
\hline $\begin{array}{l}\text { Nevirapine and } \\
\text { replacement feeding }\end{array}$ & $\begin{array}{l}\text { Average } \\
\text { (preventive) }\end{array}$ & 24.9 & $\begin{array}{l}\text { Average } \\
\text { (preventive) }\end{array}$ & 36.3 & Preventive & 0 & 24.9 & Preventive & 0 & General, all ages & 21 and 41 & 21.0 \\
\hline Effective antenatal care & Antenatal care & 25.3 & Antenatal care & 12.0 & Preventive & 0 & 12.0 & Preventive & 0 & General, all ages & 21 and 41 & 21.0 \\
\hline $\begin{array}{l}\text { Skilled maternal and } \\
\text { immediate neonatal care }\end{array}$ & Antenatal care & 25.3 & $\begin{array}{l}\text { Average } \\
\text { (antenatal + } \\
\text { postnatal) }\end{array}$ & 23.0 & Preventive & 0 & 23.0 & Preventive & 0 & General, all ages & 21 and 41 & 21.0 \\
\hline $\begin{array}{l}\text { Antibiotics for } \\
\text { premature rupture of } \\
\text { membranes }\end{array}$ & Antenatal care & 25.3 & $\begin{array}{l}\text { Average } \\
\text { (antenatal + } \\
\text { postnatal) }\end{array}$ & 23.0 & Preventive & 0 & 23.0 & Preventive & 0 & General, all ages & 21 and 41 & 21.0 \\
\hline \multicolumn{13}{|l|}{ Group 4c interventions: } \\
\hline $\begin{array}{l}\text { Emergency obstetric } \\
\text { care }\end{array}$ & $\begin{array}{l}\text { Curative, } \\
\text { under } 5\end{array}$ & 27.3 & $\begin{array}{l}\text { Curative, } \\
\text { under } 5\end{array}$ & 18.5 & $\begin{array}{l}\text { Curative, } \\
\text { under } 5\end{array}$ & 40 & 41.0 & $\begin{array}{l}\text { Curative, } \\
\text { all ages }\end{array}$ & 77 & General, all ages & 21 and 41 & 61.5 \\
\hline $\begin{array}{l}\text { Emergency neonatal } \\
\text { care }\end{array}$ & $\begin{array}{l}\text { Curative, } \\
\text { under } 5\end{array}$ & 27.3 & $\begin{array}{l}\text { Curative, } \\
\text { under } 5\end{array}$ & 18.5 & $\begin{array}{l}\text { Curative, } \\
\text { under } 5\end{array}$ & 40 & 41.0 & $\begin{array}{l}\text { Curative, } \\
\text { all ages }\end{array}$ & 77 & General, all ages & 21 and 41 & 61.5 \\
\hline $\begin{array}{l}\text { Detection and treatment } \\
\text { of asymptomatic } \\
\text { bacteriuria }\end{array}$ & Antenatal care & 25.3 & Antenatal care & 12.0 & Preventive & 0 & 18.0 & Preventive & 0 & General, all ages & 21 and 41 & 31.5 \\
\hline $\begin{array}{l}\text { Antenatal } \\
\text { corticosteriods }\end{array}$ & Antenatal care & 25.3 & $\begin{array}{l}\text { Average } \\
\text { (antenatal + } \\
\text { postnatal) }\end{array}$ & 23.0 & Preventive & 0 & 34.5 & Preventive & 0 & General, all ages & 21 and 41 & 31.5 \\
\hline
\end{tabular}

${ }^{*}$ Data on utilisation changes in preventive care given for antenatal care, family planning, and immunisations.

†Data on utilisation changes in preventive care given for antenatal care, postnatal care, weighing, and vitamin A supplementation.

$\ddagger$ Data on utilisation changes in preventive care given only for first antenatal visits.

$\S$ Estimates adjusted upwards by $60 \%$ for poor people (thus giving an extra set of utilisation rate changes for each of the two basic scenarios). Estimates calculated by applying the weighting

factors (see appendix on bmj.com) to the median of the individual studies' published estimates.

INear zero changes observed for all preventive care (antenatal care, immunisations, and under 6 growth monitoring).

${ }^{\star \star}$ Only changes in general attendance (for all types of care) reported. 
mortality by bringing together estimates of mortality in under $5 \mathrm{~s}$ by country and cause, national coverage data for all interventions of proved efficacy, and estimates of cause specific efficacy for each intervention. ${ }^{23}$ We restricted the analysis to the 20 African countries with more than 50000 child deaths annually and with user fees in place as of 2003. The model assumed that increased contacts with health facilities occur when a child is sick and at risk of dying, a seemingly plausible assumption given that travel and other non-healthcare costs will remain even after abolition of fees.

\section{Results}

This three stage analysis shows that abolition of fees could prevent approximately 233000 deaths (estimate range $153000-305000$ ) annually in 20 African countries. This amounts to $6.3 \%$ (range $4.1-8.2 \%$ ) of deaths in children under 5 in these countries. The point estimate given reflects the application of the Ugandan experience, where poor people are assumed to be the main beneficiaries of such a policy (the range around this represents the other scenarios outlined in the methods section). Sensitivity analysis reflecting a single flat rate fee before abolition produced slightly higher estimates of the number of preventable deaths-approximately $15 \%$ higher in all the scenarios.

Most of these lives would be saved by increased use of simple curative interventions, such as antimalarials and antibiotics combating dysentery and pneumonia. Reduced deaths are also possible from increased use of preventive services, but these are of a lower magnitude and not guaranteed.

\section{Discussion}

Abolition of user fees can have an immediate and important impact on reducing child deaths. Evidence on the positive relation between out of pocket and catastrophic health expenditures suggests that it may also help to stabilise household incomes, ${ }^{14}$ although only if fees make up a substantial proportion of the costs of ill health.

However, these gains will only be sustainable if policy makers establish viable alternative financing mechanisms, which also account for increased demand for services. Without these, problems of quality (such as drug shortages and low staff motivation) may occur, which can partially or fully offset any gains from reduced prices. Even so, given that user fees have generated on average only about $5 \%$ of recurrent expenditures ${ }^{15}$ the extra money needed to make up for lost fee revenues and increased resource use would probably be very low relative to the benefit of lives saved.

Future research should analyse the costs of abolition of fees in different country contexts, while also exploring the feasibility of alternative financing options. Replacing user fees with more equitable financing methods should be seen as an effective first step towards improving children's access to healthcare services and achieving the millennium development goals for health. It is by no means a complete solution-investment and policies to improve the quality of health care are urgently needed, along with better management of implementation processes. Nevertheless, as the recent UN Millennium Project

\section{What is already known on this topic}

User fees (charges for health care at the point of use) are in place in most sub-Saharan African countries

Such fees do not generate much revenue, are unlikely to improve allocative efficiency, and often disproportionately affect poor people

\section{What this study adds}

Abolition of user fees could have an immediate and substantial impact on child mortality, preventing an estimated 233000 deaths annually in 20 African countries

emphasised, abolition of user fees is likely to represent a "quick win." ${ }^{16}$

We acknowledge comments and suggestions from Lucy Gilson, Julie Morris, and Alaka Singh.

Contributors: CJ contributed to the overall methodology, writing up, and main research and is the guarantor. SSM contributed to the methodology, especially adaptation of the Bellagio child survival impact model, as well as editing the manuscript. RK contributed to the methodology, especially adjustment of the classification system for key child health interventions. AT contributed to the methodology as well as editing the manuscript. All authors approved the final version.

Funding: This research was commissioned and financed by Save the Children Fund UK.

Competing interests: None declared.

Ethical approval: Not needed.

1 Arhin-Tenkorang D. Mobilizing resources for health: the case for user fees revisited Geneva: World Health Organization, 2000. Commission on Macroeconomics and Health (CMH) Working Paper Series no WG3:6.) Macroeconomics and Health (CMH) Working Paper Series no W).

2 Jones G, Steketee RW, Black RE, Bhutta ZA, Morris SS, Bellagio Child Survival Study Group. How many child deaths can we prevent this year? Lancet 2003;362:65-71.

3 Darmstadt GL, Bhutta ZA, Cousens S, Adam T, Walker N, de Bernis L. Evidence-based, cost-effective interventions: how many lives of newborn babies can we save? Lancet 2005;365:977-88

4 Bitrán R, Giedion U. Waivers and exemptions for health services in developing countries. Washington, DC: World Bank, 2003. (Social Protection countries. Washington, DC: Worl Bank, Discussion Paper Series no 0308.) http://wbln0018.worldbank.org HDNet/hddocs.nst/0/2327d 7515 20 Sep 2005)

5 Nabyonga J, Desmet M, Karamagi H, Kadama PY, Omaswa FG, Walker O. Abolition of cost-sharing is pro-poor: evidence from Uganda. Health Policy Plan 2005;20:100-8.

6 Burnham GM, Pariyo G, Galiwango E, Wabwire-Mangen F. Discontinuation of cost sharing in Uganda. Bull World Health Organ 2004:82:187-95.

7 Deininger K, Mpuga P. Economic and welfare effects of the abolition of health user fees: evidence from Uganda. Washington, DC: World Bank, 2004. (Research working paper no 3276.) http://ideas.repec.org/p/wbk/ wbrwps/3276.html (accessed 20 Sep 2005).

8 Fafchamps M, Minten B. Public service provision, user fees and political turmoil. Cornell Food and Nutrition Policy Program, 2004. (WP 155.) http://ideas.repec.org/p/wpa/wuwpdc/0409039.html (accessed 20 Sep 2005)

9 Mwabu G, Mwanzia J, Liambila W. User charges in government health facilities in Kenya: effect on attendance and revenue. Health Policy Plan 1995:10:164-70.

10 Wilkinson D, Gouws E, Sach M, Karim SS. Effect of removing user fees on attendance for curative and preventive primary health care services in rural South Africa. Bull World Health Organ 2001:79:665-71.

11 Gertler P, Van der Gaag J. The willingness to pay for medical care. Baltimore: Johns Hopkins University Press, 1990.

12 Sauerborn R, Nougtara A, Latimer E. The elasticity of demand for health care in Burkina Faso: differences across age and income groups. Health Policy Plan 1994:9:185-92

13 Witter S. An unnecessary evil? User fees for healthcare in low-income countries. London: Save the Children UK, 2005.

14 Xu K, Evans D, Kawabata K, Zeramdini R, Klavus J, Murray C. Household catastrophic health expenditure: a multicountry analysis. Lancet 2003;362:111-6.

15 Gilson L. The lessons of user fee experience in Africa. Health Policy Plan $1997: 12: 273-85$

16 UN Millennium Project. Irvesting in development: a practical plan to achieve the millennium development goals. New York: United Nations, 2005. www.unmillenniumproject.org/reports/index.htm (accessed 20 Sep 2005) 